\title{
Sinonasal Anatomic Variations and Relationship with Sinonasal Inflammatory Mucosal Disease: A Computed Tomography Study
}

\section{Sinonazal Anatomik Varyasyonlar ve Sinonazal İnflamatuar Mukozal Hastalık ile İlişkisi: Bilgisayarlı Tomografi Çalışması}

\author{
Esin Kurtulus Ozturk', @Saffet Ozturk2, @Sukru Turan³, ®Berat Acu ${ }^{4}$ \\ ${ }^{1}$ Kutahya University of Health Sciences Faculty of Medicine, Department of Radiology, Kütahya, Turkey \\ ${ }^{2}$ Sungurlu State Hospital, Department of Radiology, Çorum, Turkey \\ ${ }^{3}$ Sungurlu State Hospital, Department of Otorhinolaryngology, Çorum, Turkey \\ ${ }^{4}$ Osmangazi University Faculty of Medicine, Department of Radiology, Eskisehir, Turkey
}

\begin{abstract}
Objective: To evaluate sinonasal anatomic variations on the paranasal computed tomography (CT) scans and to investigate association with sinonasal inflammatory mucosal disease.

Materials and Methods: Between January 2019 and December 2019, paranasal CT scans of 279 adult patients were retrospectively analyzed. Patients data were obtained from medical and imaging records. On CT examinations, each anatomic variation was evaluated with respect to side and bilaterality. We investigated statistically coexistence between anatomic variations and presence of sinonasal inflammatory mucosal disease.

Results: Our results showed high prevalence of sinonasal anatomic variations. The most common anatomic variation was nasal septal deviation (65.2\%), followed by concha bullosa (41.6\%)and septal spur (28.7\%). We found a statistically significant relationship between concha bullosa and sinonasal inflammatory mucosal disease $(p=0.009)$ which was observed especially in bulbous $(p=0.048)$ and extensive types $(p=0.017)$. No significant association was noted with the other anatomic variations.

Conclusion: Concha bullosa, particularly bulbous and extensive types have a tendency to cause sinonasal inflammatory mucosal disease.
\end{abstract}

Keywords: Sinonasal cavity, anatomic variation, computed tomography, mucosal disease, rhinosinusitis
Öz

Amaç: Paranazal bilgisayarlı tomografi (BT) incelemeleri değerlendirilereksinonazal anatomikvaryasyonlarve bu varyasyonların sinonazal inflamatuar mukozal hastalık ile ilişkisinin ortaya konması amaçlandı.

Gereç ve Yöntem: Ocak 2019 ile Aralık 2019 arasında 279 yetişkin hastanın paranazal BT incelemeleri retrospektif analiz edildi. Tıbbi ve görüntüleme kayıtlarından hasta verileri elde edildi. BT incelemelerinde her anatomik varyasyon yerleşimine göre kaydedildi. Anatomik varyasyonlar ile sinonazal inflamatuar mukozal hastalığın birlikteliği istatistiksel yöntemler kullanılarak araştırıldı.

Bulgular: Bu çalışmada sinonazal anatomik varyasyonların oldukça yüksek prevalansı olduğunu gösterdik. En sık görülen anatomik varyasyon nazal septal deviasyon $(\% 65,2)$ iken, bunu konka bülloza $(\% 41,6)$ ve septal spur $(\% 28,7)$ izledi. Özellikle bulböz $(p=0,048)$ ve yaygın $(p=0,017)$ tiplerinde olmak üzere konka bülloza $(p=0,009)$ ile sinonazal inflamatuar mukozal hastalık arasında istatistiksel olarak anlamlı bir ilişki bulduk. Diğer anatomik varyasyonlarla istatiksel anlamlı bir ilişki saptanmadı.

Sonuç: Özellikle bulböz ve yaygın tipleri olmak üzere konka büllozanın, sinonazal inflamatuar mukozal hastalığa neden olma eğilimi vardır.

Anahtar Kelimeler: Sinonazal kavite, anatomik varyasyon, bilgisayarlı tomografi, mukozal hastalık, rinosinüzit.

Corresponding (IIletişim): Esin Kurtulus Ozturk, Kutahya University of Health Sciences Faculty of Medicine, Department of Radiology, Kütahya, 43100, Turkey

E-mail (E-posta): e.kurtulus@hotmail.com

Received (Geliş Tarihi): 02.06.2020 Accepted (Kabul Tarihi): 16.08.2020 


\section{INTRODUCTION}

Anatomic variations in sinonasal cavity are highly prevalent and thought to be predisposing factors for the development of sinonasal disease or surgical complications. For the evaluation of sinonasal cavity, plain radiographs were traditionally initial imaging modality. Due to overlapping anatomic structures conventional radiography has now been replaced by highresolution $\mathrm{CT}^{\left[{ }^{[1]}\right.}$

Sinonasal inflammatory mucosal diseases (SIMD) also known as allergic rhinitis or rhinosinusitis, are one of the most common health problems affecting children and adults around the world. ${ }^{[2]} \mathrm{CT}$ is the imaging modality of choice in assessment of the sinonasal cavity and routinely performed before undergoing functional endoscopic sinus surgery (FESS), the aim of which is to restore the normal mucociliary drainage pathways. ${ }^{[1,3]}$ Therefore it is essential for radiologist to report the anatomy of the drainage pathways and clinical important anatomic variations. Also knowing the details of the anatomy of the sinonasal cavity and the extent of pneumatization can guide the surgeon to avoid complications. ${ }^{[4,5]}$

Recently several studies have investigated the relationship between sinonasal anatomic variations and SIMD however, there has been no consensus whether anatomic variation may play a significant role in the etiology of any sinus disease. Thus this study aims to evaluate the sinonasal anatomic variations on the paranasal CT scans and to investigate the relationship with SIMD.

\section{MATERIAL AND METHOD}

We retrospectively reviewed the medical records of 279 adult patients ( $\geq 18$ years) who underwent paranasal CT scan with suspicion of sinonasal abnormality from January 2019 to December 2019. Cases with prior history of sinonasal surgery, trauma, polyposis, malignancy or congenital malformation were excluded. For eligible cases, medical charts were reviewed for demographic characteristics and CT findings.

CT scans were performed without contrast using 16-slice CT scanner (Toshiba Alexion Advance Edition 16, Japan). All scans were obtained using $3 \mathrm{~mm}$ thickness in axial and coronal planes with sagittal reconstruction. Evaluation was performed by two experienced radiologists ( 5 and 7 years of experience) retrospectively.

On CT examinations, patients were considered positive who had one of the following anatomic variations: nasal septal deviation, septal spur, concha bullosa (lamellar, bulbous and extensive type), paradoxical middle turbinate, infraorbital ethmoidal (Haller) cell, sphenoethmoidal (Onodi) cell, uncinate cell, agger nasi cell, crista galli pneumatization, anterior clinoid process pneumatization, infraorbital nerveprotrusion into maxillary sinus and vidian nerve protrusion into sphenoid sinus. Each anatomic variation was evaluated with respect to side and bilaterality. As similar to previous studies the following imaging findings were considered as SIMD:

- Presence of diffuse mucosal thickening with $\geq 5 \mathrm{~mm}$ in the frontal, maxillary, and sphenoid sinuses

- Presence of air-fluid level or partial/total opacification in any sinus.

- Reactive adjacent bone changes such as sclerosis, decalcification, and erosion. ${ }^{[4]}$

Then all patients were distributed into two groups according to imaging findings: with or without radiologically SIMD. The role of anatomic variations on SIMD was evalauted by comparison with the two groups.

Data obtained were analyzed using the IBM SPSS Statistics software, version 24.0 (SPSS Inc, Chicago, IL, USA.) Continuous variables were expressed as median (minimum-maximum) and categorical values as number (percentage). The distributions of the continuous were tested for normality by using the Shapiro-Wilk test. The chi-square test was used to significance the correlation between the independent two groups. A $\mathrm{p}$-value $\leq 0.05$ was considered as statistically significant.

This retrospective study was approved by Kütahya Sağlık Bilimleri University Non-Interventional Research Ethics Board (06 February 2020, IRB number: 2020/03-18) and written informed consent was obtained from each patient before the study.

\section{RESULTS}

A total of 279 patients were (female/male : 158/121; mean age: $41 \pm 15$ years, range 18-91 years) included in this study. Anatomic variations in sinonasal cavity were noted on 263 (94.3\%) CT scans. An anatomic variation no observed in 16 (5.6\%) patients. Anatomic variations were detected mostly around the ostiomeatal unit. The most frequent anatomic variation observed was nasal septal deviation (65.2\%), followed by concha bullosa (41.6\%), septal spur (28.7\%), vidian nerve protrusion into sphenoid sinus (25.4\%) Haller cell (21.9\%), agger nasi cells (19.7\%), Onodi cell (18.3\%), anterior clinoid process pneumatization (17.9\%), infraorbital nerveprotrusion into maxillary sinus $(12.5 \%)$, uncinate cell $(10 \%)$, paradoxical middle turbinate $(5.7 \%)$, crista galli pneumatization (5\%) (Figure 1 and 2). Right-sided nasal septal deviation (33\%) was found to be slightly more common than left-sided and S-curved deviation (27.6\% and $4.7 \%$, respectively). Septal spurs were more frequently associated with nasal septal deviation except for only $0.7 \%$ patients. All concha bullosa were detected in middle turbinate and the lamellar type was the most common type accounting for $20.1 \%$ of all patients. Most anatomic variation observed on the left side whereas Onodi cell was seen more on the right side. Also bilaterality was observed predominantly among concha bullosa, infraorbital nerveprotrusion and vidian nerve protrusion into sinus. The frequencies of the anatomic variations of paranasal 

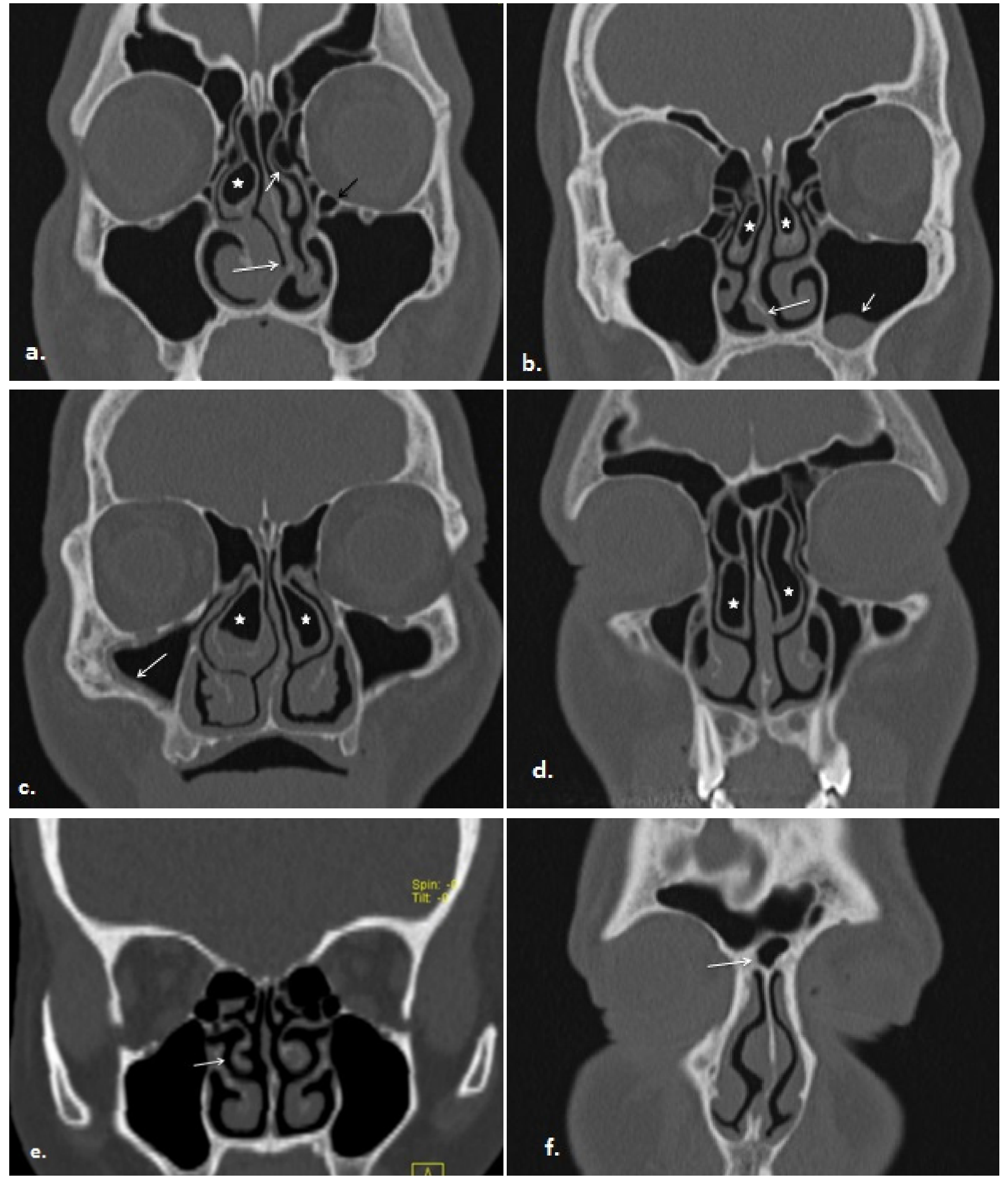

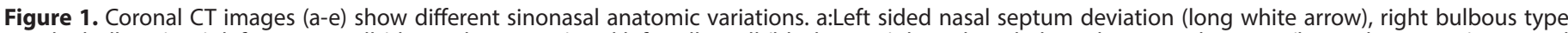

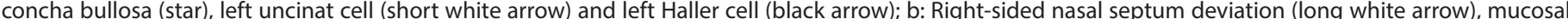

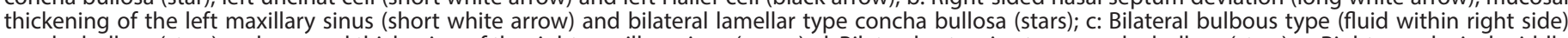

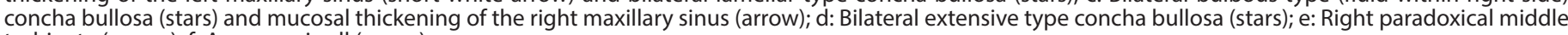
turbinate ( arrow); f: Agger nasi cell (arrow). 

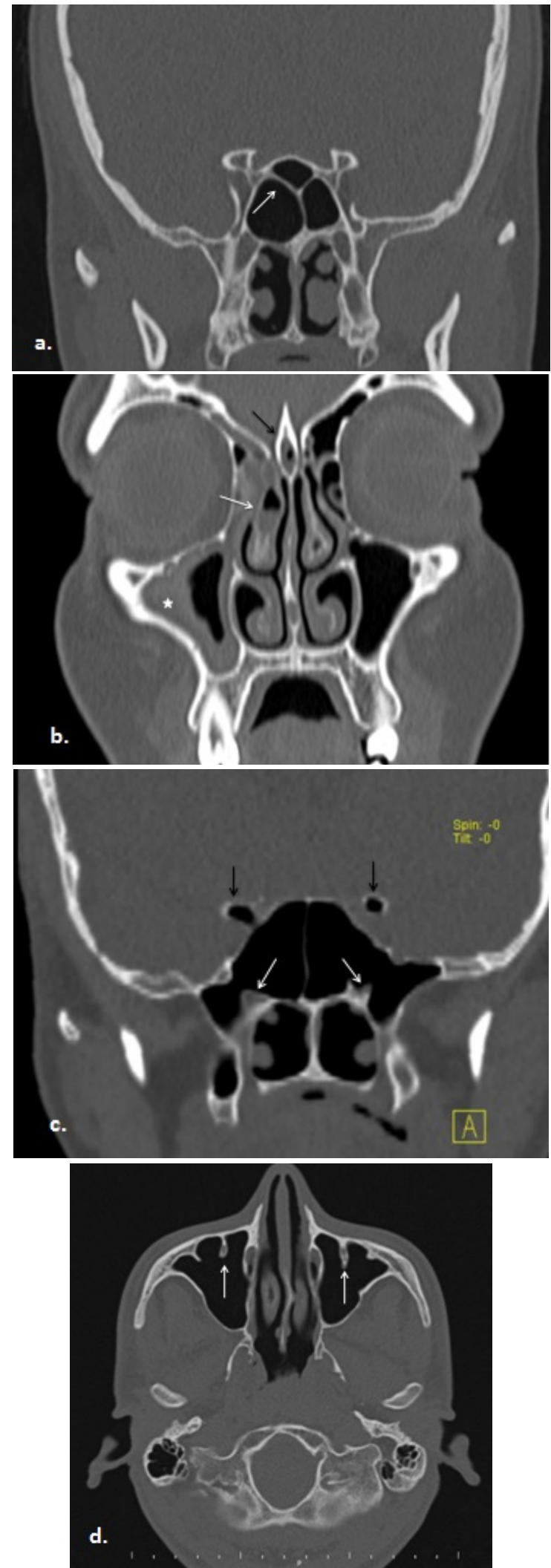

Figure 2. Coronal (a-c) and axial (d) CT images show different sinonasal anatomic variations. a: Onodi cell (arrow); b: Mucosal thickening within the pneumatized crista galli (black arrow) and right maxillary sinus (star) and fluid within right concha bullosa (white arrow); c: Bilateral anterior clinoid process pneumatization(black arrows) and bilateral vidian canal protrusion into the sphenoid sinus (white arrows); d: Bilateral maxillary nerve protrusion into the maxillary sinus ( arrows).
Table 1. Patients' characteristics and the prevelance of sinonasal anatomic variations

n(\%)

Total number of patients 279

Age -year, mean \pm standard deviation, (range)

$41 \pm 15(18-91)$ years

\section{Gender}

Female $158(56.6 \%)$

Male $121(43.4 \%)$

Presence of sinonasal mucosal inflammatory disease $172(61.6 \%)$

Anatomic variation $263(94.3 \%)$

Septal Deviation $182(65.2 \%)$

Right-sided $92(33 \%)$

Left-sided $77(27.6 \%)$

S-curved $13(4.7 \%)$

Septal spur $\quad 80(28.7 \%)$

Septal spur with septal deviation $78(27.9 \%)$

Right-sided $\quad 37(13.3 \%)$

Left-sided $39(13.9 \%)$

Only septal spur $2(0.7 \%)$

Left-sided

\begin{tabular}{lc}
\hline Concha bullosa & $118(41.6 \%)$ \\
Right-sided & $34(12.2 \%)$ \\
Left-sided & $32(11.5 \%)$ \\
Bilateral & $52(18.6 \%)$ \\
\hline Lamellar type & $56(20.1 \%)$ \\
Bulbous type & $25(9 \%)$ \\
Extensive type & $35(12.5 \%)$ \\
\hline Paradoxical middle turbinate & $16(5.7 \%)$ \\
Right-sided & $2(0.7 \%)$ \\
Left-sided & $14(5 \%)$ \\
\hline Agger nasi cell & $55(19.7 \%)$ \\
\hline Haller cell & $61(21.9 \%)$ \\
Right-sided & $28(10 \%)$ \\
Left-sided & $31(11.1 \%)$ \\
Bilateral & $2(0.7 \%)$ \\
\hline Onodi cell & $51(18.3 \%)$ \\
Right-sided & $32(11.5 \%)$ \\
Left-sided & $17(6.1 \%)$ \\
Bilateral & $2(0.7 \%)$ \\
\hline Uncinate cell & $28(10 \%)$ \\
Right-sided & $12(4.3 \%)$ \\
Left-sided & $15(5.4 \%)$ \\
Bilateral & $1(0.4 \%)$ \\
\hline Anterior clinoid process pneumatization & $50(17.9 \%)$ \\
Right-sided & $2(0.7 \%)$ \\
Left-sided & $26(9.3 \%)$ \\
Bilateral & $22(7.9 \%)$ \\
\hline Crista galli pneumatization & $14(5 \%)$ \\
\hline Protrusion of the maxillary nerve into maxillary sinus & $35(12.5 \%)$ \\
Right-sided & $2(0.7 \%)$ \\
Left-sided & $8(2.9 \%)$ \\
Bilateral & $25(9 \%)$ \\
\hline Protrusion of the vidian nerve into sphenoid sinus & $71(25.4 \%)$ \\
Right-sided & $6(2.2 \%)$ \\
Left-sided & $19(6.8 \%)$ \\
Bilateral & $46(16.5 \%)$ \\
\hline
\end{tabular}


sinuses were summarized in Table 1.

SIMD was seen in 172 patients (61\%) the remaining patients were considered as control group. Anatomic variations of sinonasal cavity were also associated with high prevalencerate of SIMD varying from $52.7 \%$ to $85.7 \%$. Only, there was statistically significant relation between concha bullosa and SIMD ( $p=0.009$ ). Additionally the bulbous and extensive types of concha bullosa were found significantly higher in patients with SIMD ( $p=0.048$ and $p=0.017$, respectively). No statistically significant association was found in patients with the other anatomic variations ( $p>0.05$ for all) The relation between

Table 2. The relation between sinonasal anatomic variations and sinonasal inflammatory mucosal disease

\begin{tabular}{|c|c|c|c|}
\hline & $\begin{array}{l}\text { Sinonasal } \\
\text { anatomic } \\
\text { variations }\end{array}$ & $\begin{array}{c}\text { Presence of } \\
\text { sinonasal } \\
\text { inflammatory } \\
\text { mucosal disease } \\
\mathbf{n}(\%)\end{array}$ & $\underset{\text { value* }}{\mathbf{P}}$ \\
\hline & $(+)$ & $(-)$ & \\
\hline Septal Deviation & $110(64 \%)$ & $72(36 \%)$ & 0.569 \\
\hline Septal spur & $53(66.3 \%)$ & $27(33.8 \%)$ & 0.316 \\
\hline Concha bullosa & $82(70.7 \%)$ & $34(29.3 \%)$ & 0.009 \\
\hline Lamellar type & $35(61.4 \%)$ & $22(38.6 \%)$ & 0.966 \\
\hline Bulbous type & $20(80 \%)$ & $5(20 \%)$ & 0.048 \\
\hline Extensive type & $28(80 \%)$ & $7(20 \%)$ & 0.017 \\
\hline $\begin{array}{l}\text { Paradoxical middle } \\
\text { turbinate }\end{array}$ & $10(62.5 \%)$ & $6(37.5 \%)$ & 0.943 \\
\hline Agger nasi cell & $29(52.7 \%)$ & $26(47.3 \%)$ & 0.129 \\
\hline Haller cell & $41(67.2 \%)$ & $20(32.8 \%)$ & 0.312 \\
\hline Onodi cell & $33(64.7 \%)$ & $18(35.3 \%)$ & 0.619 \\
\hline Uncinate cell & $20(71.4 \%)$ & $8(28.6 \%)$ & 0.262 \\
\hline $\begin{array}{l}\text { Anterior clinoid process } \\
\text { pneumatization }\end{array}$ & $30(60 \%)$ & $20(40 \%)$ & 0.791 \\
\hline Crista galli pneumatization & $12(85.7 \%)$ & $2(14.3 \%)$ & 0.057 \\
\hline $\begin{array}{l}\text { Protrusion of the maxillary } \\
\text { nerve into maxillary sinus }\end{array}$ & $24(68.6 \%)$ & $11(31.4 \%)$ & 0.368 \\
\hline $\begin{array}{l}\text { Protrusion of the vidian } \\
\text { nerve into sphenoid sinus }\end{array}$ & $49(69 \%)$ & $22(31 \%)$ & 0.139 \\
\hline${ }^{*} p$-value $\leq 0.05$ & & & \\
\hline
\end{tabular}

sinonasal anatomic variations and SIMD was illustrated in Table 2.

\section{DISCUSSION}

Sinonasal cavity is an important anatomical and functional unit consisting of air-filled cavities located in the bone surrounding the nasal cavity and are closely related to upper airway. ${ }^{[6]}$ Imaging of the sinonasal cavity is crucial to define anatomic structures and extent and severity of sinonasal diseases. Paranasal CT scan is an important diagnostic imaging technique in delineating accurately the normal anatomy and anatomic variations, by dramaticallly improving the evaluation compared to plain radiographs. ${ }^{[7-9]}$

FESS is the main minimally-invasive technique specifically for chronic sinusitis, which is used to restore sinus ventilation and normal sinus function. Consequently systematic CT analysis of the sinus disease, sinus drainage pathways, anatomic variations, and surrounding soft tissues leads to a crucial report which provides a road map for the surgeons prior to FESS. ${ }^{[10,11]}$ Recent developments in imaging and widespread of FESS have led to evaluate the sinonasal anatomic variations. Until now, many studies have been reported anatomic variations of sinonasal cavity with quite different prevalences. ${ }^{[1,7,11-13]}$ This wide range of prevalence could be probably depending on the diagnostic method, definition, case selection, race etc. $[3,10]$ In our study, nearly similar prevalence rates of anatomic variations were obtained when comparing with the previous findings reported in the literature.

Despite its prevalence and significant health impact, the etiology of rhinosinusitis remains incompletely understood and is thought to be multifactorial such as infection, allergy, altered immunity, different sinus drainage pathways or a combination of these factors. ${ }^{[13,14]}$ Most clinicians consider that some anatomic variations especially around the ostiomeatal unit including septal deviation, concha bullosa, middle turbinate pneumautization, agger nasi cell, uncinate cell, Haller cell may be a cause of obstruction which can contribute to rhinosinusitis. But the others such as Onodi cell, infraorbital nerve, vidian nerve or internal carotid artery protrusion into the sinuses are critical for determination of performing FESS. [15]

In literature, several researchers with comparative studies have not been yet reached a consensus whether anatomic variations play a role in development of sinus disease. Some studies have noted no significant association between these anatomic variations and rhinosinusitis. ${ }^{[16-20]}$ On the other hand, some studies have reported significant differences between the prevalence of certain anatomical variations and rhinosinusitis. ${ }^{[11]}$ In one study septal deviation, bilateral concha bullosa, medial deviation of uncinate process, Haller cell, agger nasi cell, hypertrophic ethmoidal bullawere found to be significantly associated with sinonasal mucosal diseases. ${ }^{[21]}$ Kaya et al. ${ }^{[22]}$ noted a statistically significant relationship between hypertrophy of middle concha, concha bullosa, agger nasi cells, Onodi cells, uncinate bulla, and the medial and lateral deviations of uncinate process and sinusitis. Another study showed that uncinate bulla and giant ethmoid bulla were significantly associated with sinonasal mucosal disease. ${ }^{[15]}$ Also Alkire et al. ${ }^{[23]}$ showed an association between Haller cells and recurrent acute rhinosinutsitis. In one study septal deviation, concha bullosa and infraorbital ethmoidal (Haller) cells which contribute to the narrowing of the osteomeatal complex, were associated with sinus mucosal disease. [24] In the present study we found a significant relationship between concha bullosa and SIMD. No significant difference were identified in the prevalence of of the other anatomic variations between patients with and without clinically significant radiologic evidence of SIMD. As well, bulbous and extensive type concha bullosa were found significantly higher in patients with rhinosinusitis.

With regard to the retrospective nature, some limitations need to be acknowledged. We did not have access to information 
about FESS results. It is a retrospective single-center study with a relatively small sample size. Therefore our results may not reflect entire population.

\section{CONCLUSION}

Knowing the anatomic variations is crucial for the radiologist and surgeon in order to allow accurate diagnosis and management of surgery and avoid surgical complications. The current study extends our knowledge of anatomic variations of the sinonasal cavity and contributes to the current understanding of the role of anatomic variations of the sinonasal cavity on development of SIMD. Our results confirm previous researchs that anatomic variations have a wide range ofprevalence. Also we found statistically significant relationship between concha bullosa especially bulbous and extensive types and SIMD. However several questions still remain to be answered. We believe that there is a need for multi-center studies with larger number of patients, wider range of population group in order to increase the validity and generalizability of findings.

\section{ETHICAL DECLARATIONS}

Ethics Committee Approval: The study was approved by Kütahya Sağlık Bilimleri University Non-Interventional Research Ethics Board(06 February 2020, IRB number: 2020/03-18).

Informed Consent: Because the study was designed retrospectively, no written informed consent form was obtained from patients.

Referee Evaluation Process: Externally peer-reviewed.

Conflict of Interest Statement: The authors have no conflicts of interest to declare.

Financial Disclosure: The authors declared that this study has received no financial support.

Author Contributions: All of the authors declare that they have all participated in the design, execution, and analysis of the paper, and that they have approved the final version.

\section{REFERENCES}

1. Avsever H, Gunduz K, Karakoc O, Akyol M, Orhan K. Incidental findings on cone-beam computed tomographic images: paranasal sinus findings and nasal septum variations. Oral Radiol 2018;34(1):40-8.

2. Krouse JH. Inflammatory sinonasal disease. Facial Plast Surg Clin North Am 2004;12(4):407-14.

3. Hoang JK, Eastwood JD, Tebbit CL, Glastonbury CM. Multiplanar sinus CT: a systematic approach to imaging before functional endoscopic sinus surgery. AJR Am J Roentgenol 2010;194(6):W527-36.

4. Rao VM, el-Noueam KI. Sinonasal imaging. Anatomy and pathology. Radiol Clin North Am 1998;36(5):921-39

5. Yousem DM. Imaging of sinonasal inflammatory disease. Radiology. 1993;188(2):303-14.

6. Scarfe William C. AC. Maxillofacial Cone Beam Computed Tomography. William C. Scarfe CA, editor: Springer International Publishing; 2018.
7. Perez P, Sabate J, Carmona A, Catalina-Herrera CJ, Jimenez-Castellanos J. Anatomical variations in the human paranasal sinus region studied by $C T$. J Anat 2000;197(2):221-7.

8. Bolger WE, Butzin CA, Parsons DS. Paranasal sinus bony anatomic variations and mucosal abnormalities: CT analysis for endoscopic sinus surgery. Laryngoscope 1991;101(1):56-64.

9. Scuderi AJ, Harnsberger HR, Boyer RS. Pneumatization of the paranasal sinuses: normal features of importance to the accurate interpretation of CT scans and MR images. AJR Am J Roentgenol 1993;160(5):1101-4.

10. Stammberger H. F.E.S.S.: endoscopic diagnosis and surgery of the paranasal sinuses and anterior skull base ; the Messerklinger technique and advanced applications from the Graz School: Graz, Austria : University Ear Nose and Throat Hospital; 2006.

11. Beale TJ, Madani G, Morley SJ. Imaging of the paranasal sinuses and nasal cavity: normal anatomy and clinically relevant anatomical variants. Semin Ultrasound CT MR 2009;30(1):2-16.

12. Koo SK, Kim JD, Moon JS, Jung SH, Lee SH. The incidence of concha bullosa, unusual anatomic variation and its relationship to nasal septal deviation: A retrospective radiologic study. Auris Nasus Larynx 2017;44(5):561-70.

13. Yadav RR, AnseriMA, Humagain M, Mishra D. Assessment of anatomical variations of nose and paranasal sinuses inmultidetector computed tomography. J Inst Med 2017;39:1.

14. Lee S, Lane AP. Chronic rhinosinusitis as a multifactorial inflammatory disorder. Curr Infect Dis Rep 2011;13(2):159-68.

15. Dasar U, Gokce E. Evaluation of variations in sinonasal region with computed tomography. World J Radiol 2016;8(1):98-108.

16. Shpilberg KA, Daniel SC, Doshi AH, Lawson W, Som PM. CT of Anatomic Variants of the Paranasal Sinuses and Nasal Cavity: Poor Correlation With Radiologically Significant Rhinosinusitis but Importance in Surgical Planning. AJR Am J Roentgenol 2015;204(6):1255-60.

17. Kaygusuz A, Haksever M, Akduman D, Aslan S, Sayar Z. Sinonasal anatomical variations: their relationship with chronic rhinosinusitis and effect on the severity of disease-a computerized tomography assisted anatomical and clinical study. Indian J Otolaryngol Head Neck Surg 2014;66(3):260-6.

18. Jones NS. CT of the paranasal sinuses: a review of the correlation with clinical, surgical and histopathological findings. Clin Otolaryngol Allied Sci 2002;27(1):11-7.

19. Smith KD, Edwards PC, Saini TS, Norton NS. The prevalence of concha bullosa and nasal septal deviation and their relationship to maxillary sinusitis by volumetric tomography. Int J Dent 2010;2010.

20. Stallman JS, Lobo JN, Som PM. The incidence of concha bullosa and its relationship to nasal septal deviation and paranasal sinus disease. AJNR Am J Neuroradiol. 2004;25(9):1613-8.

21. Fadda GL, Rosso S, Aversa S, Petrelli A, Ondolo C, Succo G. Multiparametric statistical correlations between paranasal sinus anatomic variations and chronic rhinosinusitis. Acta Otorhinolaryngol Ital 2012;32(4):244-51.

22. Kaya M, Cankal F, Gumusok M, Apaydin N, Tekdemir I. Role of anatomic variations of paranasal sinuses on the prevalence of sinusitis: Computed tomography findings of 350 patients. Niger J Clin Pract 2017;20(11):14818.

23. Alkire BC, Bhattacharyya N. An Assessment of Sinonasal Anatomic Variants Potentially Associated With Recurrent Acute Rhinosinusitis. The Laryngoscope 2010;120:631-4.

24. Robert J. Caughey MJJ, Charlie W. Gross, Joseph K. Han. Anatomic Risk Factors for Sinus Disease: Fact or Fiction? Am J Rhinol 2005;19(4):334-9. 